\title{
LEARNING ENGLISH AS A FOREIGN LANGUAGE IN AN INDONESIAN UNIVERSITY: A STUDY OF NON- ENGLISH DEPARTMENT STUDENTS' PREFERRED ACTIVITIES INSIDE AND OUTSIDE THE CLASSROOM
}

\author{
Urip Sulistiyo \\ Email: usulis2012@gmail.com \\ Universitas Jambi
}

\begin{abstract}
This study examines a range of learning activities used in teaching English and identifies those that students see as most helpful. The instrument used in this study was a questionnaire adopted from Willing (1988). Some modification had been made to meet the purpose of this study. The questionnaire consists of two parts. Part 1 is ethnographic data in terms of the participants' gender and field of study. Part 2 consists several items comprises students' preferred activities in learning English. Students are asked to rank the activities of each category by circling one number. Circling number 1 means it is not helpful / preferable, while circling number 4 means it is very helpful / preferable for them. Then, all the responses were analyzed using SPSS Professional Statistics. The study suggests a number of pedagogical implication for English teaching and learning for non-English department students at universities in Indonesia. The finding suggests that teachers should take preferred activities into account when they are teaching. In addition, the study also proposed some suggestions for further research. These suggestions state the need to conduct research which involves more participants to confirm the results of the current study.
\end{abstract}

Keywords: EFL, Learning Activities, Inside and Outside Classroom

\section{INTRODUCTION}

This paper is part of larger study identifying students' preferred activities in learning English as a Foreign Language (EFL). The identification of preferred learning activities is important to improve the English teaching practice at the faculty of Teacher 
Training and education of Jambi University where I am teaching English. The university is located in Jambi province, in Sumatra Island.

It is worth bearing in mind that as an English teacher, I find teaching English is not easy. I often feel unsatisfied with my teaching practice in the classroom. There are several reasons that make teaching English difficult. Firstly, I have to deal with large classes in which more than fifty students in a class. Even though the definition of large class in language learning classes context vary (Wright, 2005), this ratio is not ideal for a language classroom. Secondly, not all students who attend the English classes are motivated. English subject is a compulsory subject that means students have to learn the language for examination purposes and exposure to English is only for about two hours a week. Their low motivation and less English learning hours become an obstacle not only for me to teach English but also for them to learn it. Thirdly, the teaching focus of English at university level for nonEnglish department students is on reading skill (Sawir, 2005; Sugirin, 1999; Setiyadi, 2001). This may be because most of the textbooks used in universities are written in English beside Indonesian. So, the emphasis of teaching is on English grammar and vocabulary. This teaching emphasis is based on the assumption that students will understand an English text properly if they know the structure of English and have an adequate vocabulary. One consequence of this is that the teaching of other skills such as speaking, writing, and listening, are ignored (Sugirin, 1999).

Given that situation, the outcome of teaching English for nonEnglish department students at my university is unsatisfactory and the students' English performance is very limited. Research conducted by Exley (2005) shows that most Indonesian students are categorized as less than good in spoken and written English proficiency. This may be because, as Setyadi (2001) suggests, non-English department students are not taught how to learn English with appropriate teaching strategies. He further said that this does not happen only in Indonesia but also in other South East Asian Countries.

In this paper, I would like to argue that knowing students' preferred activities in learning English for non-English department students will help them learn English effectively. Learning activities 
inside and outside the classroom, the teacher's role, grouping arrangements, language focus, and sensory modality are the factors that can help both teacher and students achieve their goal in learning English.

Those factors have been investigated by Willing (1988) in his survey study involving 517 learners of English as a second language in Australia. In collecting the data, Willing utilized questionnaires for learners to complete. This study attempted to findquestionnaires for learners to complete. This study attempted to find out the students' learning preferred activities that might vary among group of learners. This goal was based on the assumption that the variables such as ethnic group, age, level of previous education, speaking proficiency level, and length of residence in Australia may affect students' preferred ways of learning.

Willing (1988) found that cultural backgrounds in some ways affected the learners' preferences in learning. Chinese learners, for instance, prefer that their teachers explain everything and tell all the mistakes they made during learning. Meanwhile, Arabic learners prefer to practice pronunciation and study grammar. It also found that learners' learning preferences were influenced by gender. In learning English, women like to learn new words more than men. On the other hand, men like writing everything in their notebooks more than women do.

However, the study by Willing (1988) did not reveal the learners' learning preferences by field of study. This might be because respondents of the survey research are adult migrants who do not enroll in formal education during the survey. This will be the researcher's concern to find out. It becomes important to find the major learning preferred activities of Indonesian non English department students regarding their field of study since it will be valuable information for the English teachers.

Furthermore, Willing's study was conducted in a second language context. Therefore, the replication of this study in a foreign language environment will bring different outcomes and will be useful information as Nunan (1991) states that the study conducted by 
Willing(1988) may have different result in English as a foreign language contexts.

\section{EFL TEACHING AND LEARNING IN INDONESIA}

Unlike in its neighbouring countries - such as Singapore, Hong Kong and Malaysia, where English is widely spoken as a second language - English in Indonesia is more likely to be taught and learnt only as a foreign language. This means that learning and teaching English occurs mostly in classrooms, rather than during daily communication. English learners in Indonesia do not have ready access to using English as a tool of communication during their daily lives outside the classroom. As stated by Oxford and Shearin (1994), a foreign language in this context is a language learnt only during formal education. As such, English language teaching and learning in Indonesia presents particular challenges that are not encountered in countries such as Hong Kong, where English is more commonly used on a daily basis.

Berns (1990) defined foreign language learning as learning a target language in a country that does not use this language as a speech community. Thus, in a foreign language learning context, there are few opportunities for learners to employ the target language outside the classroom because the language (English, in this case) is not used as the main device of communication among people. When a target language is seldom used outside the classroom, input and language use in the classroom are essential (Suryati, 2013).

In short, there are three factors that may influence the success of EFL teaching in Indonesia. According to Sulistiyo (2009), these are class size, student motivation and teaching focus. These three factors align with Bradford's (2007) view that less effective English learning and teaching in Indonesia is often due to classroom size and student motivation, although Bradford also includes the factor of teacher qualifications as contributing to the limited effectiveness of EFL teaching in Indonesia.

Several scholars have investigated TEFL in Indonesia. For example, Yuwono (2005) conducted research into English language teaching in Indonesia by obtaining the perspectives of school principals 
and English language teachers in Salatiga municipality, Central Java. She stated that English teaching and learning in schools in Indonesia, especially in rural areas, is not ideal. She argued that the continually revised curriculum does not seem to seriously consider factors such as teachers' qualifications, teachers' time availability, the number of students per class, and the availability of resources and facilities, which all significantly affect the success of teaching and learning English in Indonesian schools. In addition, the curriculum does not provide strategies and alternatives to address problems related to English language teaching.

According to Kirkpatrick (2007), the teaching of English in Indonesian schools and colleges has been less than satisfactory during the last few decades. Lie (2007) reported a sense of 'failure' in TEFL in Indonesia. She stated that, although English is taught and used as a foreign language in Indonesia, and there have been many years of English instruction in formal schooling, the outcomes are unsatisfactory. Previous studies have identified several factors that impede the success of language learning and teaching in Indonesia, including large class sizes, less qualified teachers, a lack of teaching facilities, and low salaries for teachers (Kirkpatrick, 2007; Sulistiyo, 2009; Yuwono, 2005).

Mbato (2013) observed similar reasons for the limited effectiveness of EFL learning and teaching in Indonesia. First, EFL learning mostly occurs in the classroom context, with English learners having limited exposure to English for communicative purposes. Second, the only source of learning is from the teachers and learning materials provided in class. Third, students learn English because it is a compulsory part of school curriculum, and subsequently may not be motivated to learn.

In summary, several factors appear to impede the success of teaching and learning EFL in Indonesia. Teacher qualifications and low English proficiency, classroom size, students' motivation, classroomoriented learning, and limited sources of learning are factors that strongly influence EFL teaching and learning success (Bradford, 2007; Kassing, 2011; Kirkpatrick, 2007; Sulistiyo, 2009; Yulia, 2013). 
Therefore, the study that investigates how students from nonEnglish department at University level learning English inside and outside the classroom in EFL contexts is crucially needed to provide insights of what preferred activities the students might have in their efforts to learn English both dependently and independently. Having ideas how the students learn English will be helpful for English teachers to facilitate the students in proper ways to master English as well as it will be helpful to help students find their own ways of learning.

\section{METHODS}

This study is part of a larger research that seeks the students preferred activities in learning English at University level in one of universities in Indonesia. The research design used in this study is a survey research. The survey is a kind of research which aims to collect the data at a certain time encompassing description of a condition, identification of standards comparing to existing condition, and relation between one event to another (Cohen and Morrison, 2000). This study is intended to gather the data which describe students' preferences in their effort to learn English.

In collecting the data, the questionnaire was used. According to Crowl (1983) questionnaires can be used in the survey if the sample size is considered large. This survey included all non-English department students from economics, Biology, and Physics departments. The total number of participants is 170 . This study is a complete census survey in which information is collected from all member of a population. According to Wiersma and Jurs (2005) if all population is included in the survey, the survey is called a cens (2005) if all population is included in the survey, the survey is called a census The Development of the Questionnaire

The questionnaire used in this study was adapted from students' learning preferences questionnaire by Willing (1988). The questionnaire consists of two parts. Part 1 is regarding to ethnographic data in terms of the participants' gender and field of study. Part 2 consists of 15 items on two pages comprises: question 1-7 dealt with preferred classroom activities; question 8 -15 related to different outside class activities. Respondents are asked to rank the activities of 
each category by circling one number. Circling number $\mathbf{1}$ means it is not helpful /preferable, while circling number 4 means it is very helpful / preferable for them.

The modified version of the questionnaire was piloted in a group of Indonesian students studying in Australian universities. The pilot group was students who are studying in some majors other than English. The consideration to choose this group is to meet the similar characteristics between pilot group and the real participants from whom the data will be collected as Wiersma and Jurs (2005) state that the group used for the pilot run should be in the position to make valid judgment about the items.

This pilot run was intended to identify possible misunderstandings, ambiguities, and inadequate items. It was found that in part 1 of the questionnaire, the question asking the length of learning English became irrelevant since the study is trying to find out the students' learning preferences affected by different gender and field of study only. Next, the blank space provided that was intended to gain any possible activities that participants might add were omitted. The omission was done because none of the participants in the pilot filled out the blank to add some possible activities.

It was also found that instruction used in the questionnaire is understandable since it used a simple and clear language. The time spent to answer all questions in the questionnaire is 10 minutes in average. The questionnaire was given in English and was not translated in Bahasa Indonesia, Indonesian language. The reasons are because the language used in the questionnaire is simple and clear and it is believed that the participants will be able to answer the questions effectively since they have been studying English in junior high school and senior high school before attending university.

\section{Data Collection}

The revised questionnaire was sent to Indonesia and handed out to all participants to complete on $30^{\text {th }}$ May 2011. The questionnaires were administered to intended participants once the researcher obtained permission from Graduate School of Education Ethics Committee to conduct a research involving human subjects. The questionnaires were distributed to 170 participants. The completion of 
the questionnaire is voluntary and the participants were not required to provide their names. The participants felt free not to complete the questionnaire and left the questionnaire blank. The completed questionnaires should be placed in a sealed box provided.

In distributing and collecting the questionnaires, the researcher was assisted by a colleague who was agree to help collect the data from all participants in Jambi, Indonesia and send them back to the researcher in Australia. To help the colleague in the process of data collection, a set of instruction was given to make sure the procedure of data collection was right. The details are as follows:

1. Every students is to receive a questionnaire to complete

2. The questionnaire will take 10-15 minutes to complete

3. The return of a questionnaire means that student has consented to participate in the study

4. Participants are not required to give their name

5. Participants are free not to complete the questionnaire

6. Participants are asked to rank the activities that they find helpful by circling a response, as the instruction indicated

7. Participants are asked to return completed or uncompleted questionnaire in a sealed box provided.

(Adapted from: Phan, 2002)

After the questionnaires had been returned, each questionnaire was given a code number. Then, all the responses were analyzed using SPSS Professional Statistics. SPSS stands for Statistical Package for the Social Science. In this survey, the researcher used frequency distributions and histograms in statistical procedures to analyze individual item of each category and make a comparison among the items to find out which items of six categories get the most preference and the least preference from the respondent.

\section{FINDING AND DISCUSSION}

This section presents finding and discussion regarding students' preferred activities in the classroom that might helpful for them to learn English. The learning activities such as reading, listening to cds and cassettes, playing games, having conversation, watching TV program or movie are presented and discussed 
Table 1. Reading Activity

\begin{tabular}{|c|c|c|c|c|c|}
\hline \multicolumn{2}{|c|}{} & Frequency & Percent & $\begin{array}{c}\text { Valid } \\
\text { Percent }\end{array}$ & $\begin{array}{c}\text { Cumulative } \\
\text { Percent }\end{array}$ \\
\hline Valid & Not helpful & 7 & 5.0 & 5.0 & 5.0 \\
\cline { 2 - 6 } & Less helpful & 21 & 15.1 & 15.1 & 20.1 \\
\cline { 2 - 6 } & Helpful & 47 & 33.8 & 33.8 & 54.0 \\
\cline { 2 - 6 } & Very helpful & 64 & 46.0 & 46.0 & 100.0 \\
\cline { 2 - 6 } & Total & 139 & 100.0 & 100.0 & \\
\hline
\end{tabular}

Figure 1. Mean and Hisstogram for Reading Activity

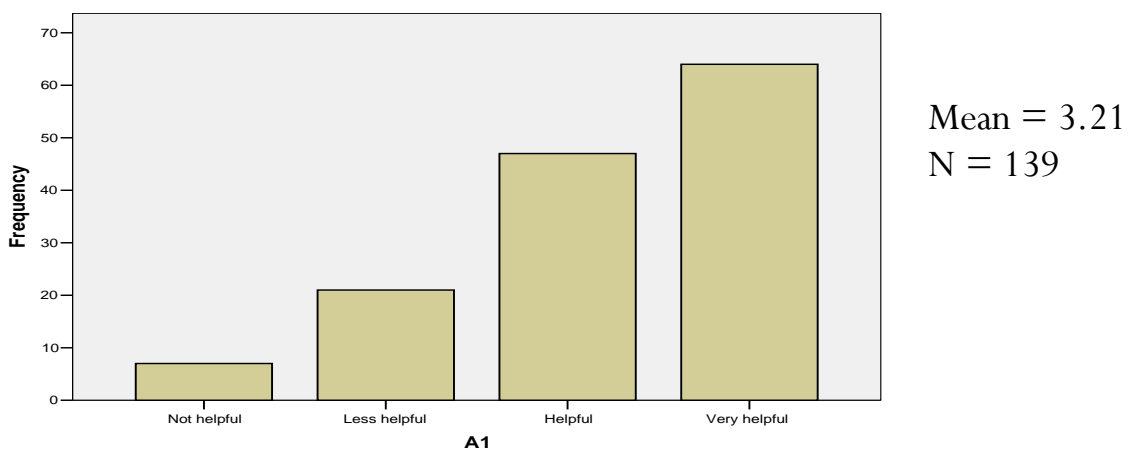

The total number of students who responded to reading activity was 139. As displayed in figure. 1 , the mean score for this activity was 3.21 which go towards to the very helpful end of the scale. Most of the students responded either helpful (33.8\%) or very helpful (46\%) representing a total of $79.8 \%$ of the students. The students found that reading activity is helpful in learning English. Only 5\% of the students found it not helpful and $15.1 \%$ of the students found it less helpful.

Table 2. Listening to CDs and Cassettes

\begin{tabular}{|c|c|c|c|c|c|}
\hline \multicolumn{2}{|c|}{} & Frequency & Percent & $\begin{array}{c}\text { Valid } \\
\text { Percent }\end{array}$ & $\begin{array}{c}\text { Cumulative } \\
\text { Percent }\end{array}$ \\
\hline Valid & Not helpful & 6 & 4.3 & 4.3 & 4.3 \\
\cline { 2 - 6 } & Less helpful & 16 & 11.5 & 11.5 & 15.8 \\
\cline { 2 - 6 } & Helpful & 52 & 37.4 & 37.4 & 53.2 \\
\cline { 2 - 6 } & $\begin{array}{c}\text { Very } \\
\text { helpful }\end{array}$ & 65 & 46.8 & 46.8 & 100.0 \\
\cline { 2 - 6 } & Total & 139 & 100.0 & 100.0 & \\
\hline
\end{tabular}


Figure 2. Mean, and Histogram for Listening to Cds and

\section{Cassettes}

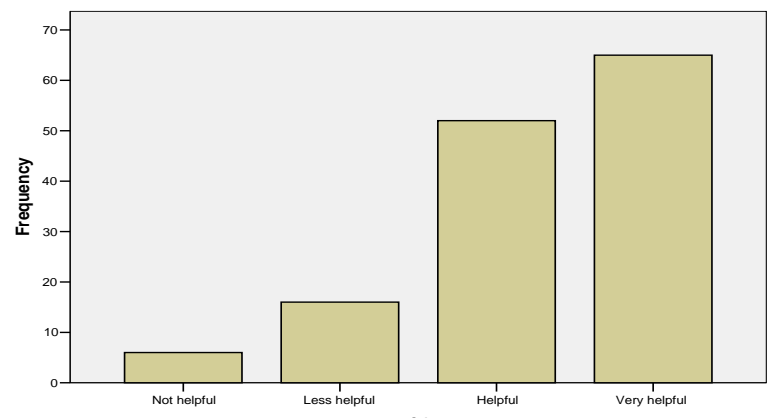

Mean $=3.27$

$\mathrm{N}=139$

According to the result shown in table.2, most students found that listening to CDs and Cassettes are helpful for them learn English. This was evidence in the fact that $84.2 \%$ of the total 139 participating students chose to answer helpful (37.4\%) and very helpful(46.8\%) so that the mean score for the statement at 3.27 on a scale 4 points showed that listening to CDs and Cassettes is the activity that can help students to learn English.

Table 3. Playing Games

\begin{tabular}{|c|c|c|c|c|c|}
\hline \multicolumn{2}{|c|}{} & Frequency & Percent & $\begin{array}{c}\text { Valid } \\
\text { Percent }\end{array}$ & $\begin{array}{c}\text { Cumulative } \\
\text { Percent }\end{array}$ \\
\hline \multirow{4}{*}{ Valid } & Not helpful & 8 & 5.8 & 5.8 & 5.8 \\
\cline { 2 - 6 } & Less helpful & 49 & 35.3 & 35.3 & 41.0 \\
\cline { 2 - 6 } & Helpful & 55 & 39.6 & 39.6 & 80.6 \\
\cline { 2 - 6 } & Very helpful & 27 & 19.4 & 19.4 & 100.0 \\
\cline { 2 - 6 } & Total & 139 & 100.0 & 100.0 & \\
\hline
\end{tabular}

Figure 3. Mean, and Histogram for Playing Games

A3

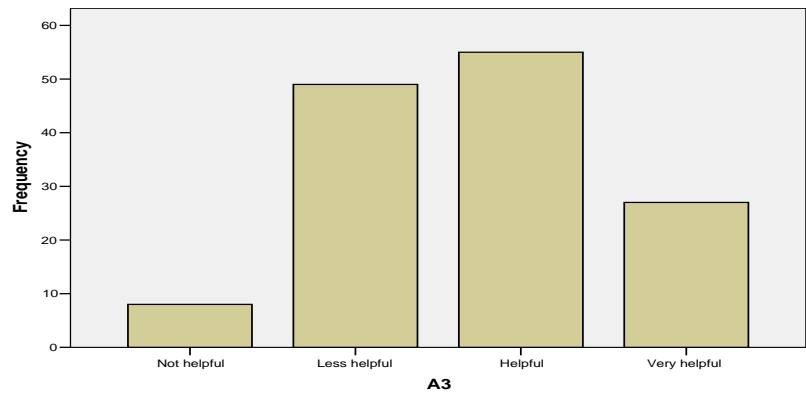

Mean $=2.73$

$\mathrm{N}=139$ 
As indicated in table. 3,59 percent of students reported some degree of helpfulness of playing games activity in their learning. In particular, 39.6 percent of students identified playing games as helpful activity, with 19.4 percent indicating that the activity is very helpful. However, 41 percent of respondents reported that playing games is either not helpful or less helpful activity in learning English. It is clear that students were split on this activity.

\section{Table 4. Having Conversations}

\begin{tabular}{|c|c|c|c|c|c|}
\hline \multicolumn{2}{|c|}{} & Frequency & Percent & $\begin{array}{c}\text { Valid } \\
\text { Percent }\end{array}$ & $\begin{array}{c}\text { Cumulative } \\
\text { Percent }\end{array}$ \\
\hline \multirow{4}{*}{ Valid } & Not helpful & 2 & 1.4 & 1.4 & 1.4 \\
\cline { 2 - 6 } & Less helpful & 8 & 5.8 & 5.8 & 7.2 \\
\cline { 2 - 6 } & Helpful & 33 & 23.7 & 23.7 & 30.9 \\
\cline { 2 - 6 } & Very helpful & 96 & 69.1 & 69.1 & 100.0 \\
\cline { 2 - 6 } & Total & 139 & 100.0 & 100.0 & \\
\hline
\end{tabular}

Figure 4. Mean, and Histogram for having conversations

A4

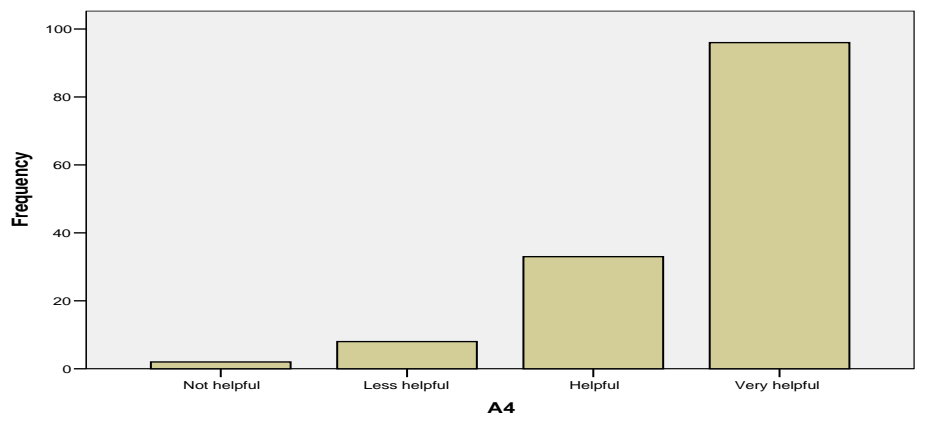

Mean $=3.60$

$\mathrm{N}=139$

Overall, the students found conversation activity is very helpful and preferable for them to learn English as indicated by mean score of 3.60. As indicated in table.4, 69.1 percent of respondents found that having conversation is very helpful and 23.7 percent of respondents found it helpful. 
Table 5. Watching Film or Video

\begin{tabular}{|c|c|c|c|c|c|}
\hline \multicolumn{2}{|c|}{} & Frequency & Percent & $\begin{array}{c}\text { Valid } \\
\text { Percent }\end{array}$ & $\begin{array}{c}\text { Cumulative } \\
\text { Percent }\end{array}$ \\
\hline Valid & Not helpful & 4 & 2.9 & 2.9 & 2.9 \\
\cline { 2 - 6 } & Less helpful & 22 & 15.8 & 15.8 & 18.7 \\
\cline { 2 - 6 } & Helpful & 64 & 46.0 & 46.0 & 64.7 \\
\cline { 2 - 6 } & Very helpful & 49 & 35.3 & 35.3 & 100.0 \\
\cline { 2 - 6 } & Total & 139 & 100.0 & 100.0 & \\
\hline
\end{tabular}

Figure.5. Mean, and Histogram for watching film or video

A5

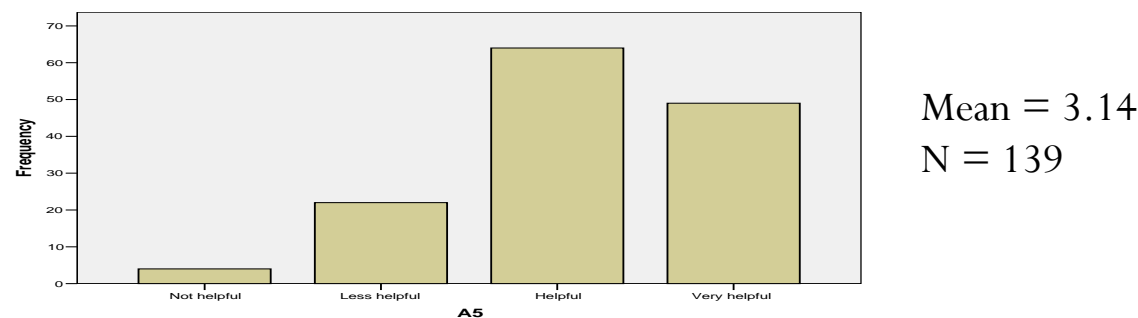

The mean of 3.14 for watching films or videos showed that students found that activity is helpful. In particular, 46 percent of students chose helpful for the activity and 35.3. percent of students chose very helpful. While, students who chose either not helpful or less helpful for the activity is only 18.7 percent as opposed to 81.3 percent of students who chose either helpful or very helpful for the activity.

Table.6. Writing in notebook

\begin{tabular}{|c|c|c|c|c|c|}
\hline \multicolumn{2}{|c|}{} & Frequency & Percent & $\begin{array}{c}\text { Valid } \\
\text { Percent }\end{array}$ & $\begin{array}{c}\text { Cumulative } \\
\text { Percent }\end{array}$ \\
\hline \multirow{3}{*}{ Valid } & Not helpful & 4 & 2.9 & 2.9 & 2.9 \\
\cline { 2 - 6 } & Less helpful & 28 & 20.1 & 20.1 & 23.0 \\
\cline { 2 - 6 } & Helpful & 61 & 43.9 & 43.9 & 66.9 \\
\cline { 2 - 6 } & Very helpful & 46 & 33.1 & 33.1 & 100.0 \\
\cline { 2 - 6 } & Total & 139 & 100.0 & 100.0 & \\
\hline
\end{tabular}


Figure 6. Mean, and Histogram for writing in notebook

A6

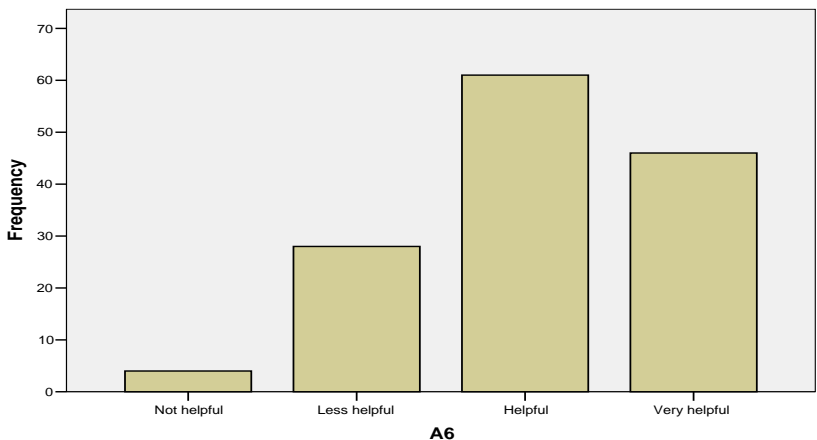

Mean $=3.07$

$\mathrm{N}=139$

With only 23 percent of respondents chose either not helpful or less helpful, the results once again suggest that students found writing in notebooks is the activity that can help them in learning English. 77 percent of students chose both helpful and very helpful with 43.9 percent of students found the activity helpful and 33.1 percent of students found it very helpful.

\section{Students' Preferred Learning Activities outside the Classroom}

Another area of this investigation involved activities undertaken outside the classroom. This section reports students' responses to these activities.

\section{Table 7. Reading at home}

\begin{tabular}{|c|c|c|c|c|c|}
\hline \multicolumn{2}{|c|}{} & Frequency & Percent & $\begin{array}{c}\text { Valid } \\
\text { Percent }\end{array}$ & $\begin{array}{c}\text { Cumulative } \\
\text { Percent }\end{array}$ \\
\hline Valid & Not helpful & 9 & 6.5 & 6.5 & 6.5 \\
\cline { 2 - 6 } & Less helpful & 34 & 24.5 & 24.5 & 30.9 \\
\cline { 2 - 6 } & Helpful & 47 & 33.8 & 33.8 & 64.7 \\
\cline { 2 - 6 } & Very helpful & 49 & 35.3 & 35.3 & 100.0 \\
\cline { 2 - 6 } & Total & 139 & 100.0 & 100.0 & \\
\hline
\end{tabular}


Figure 7. Mean, and Histogram for reading at home

F1

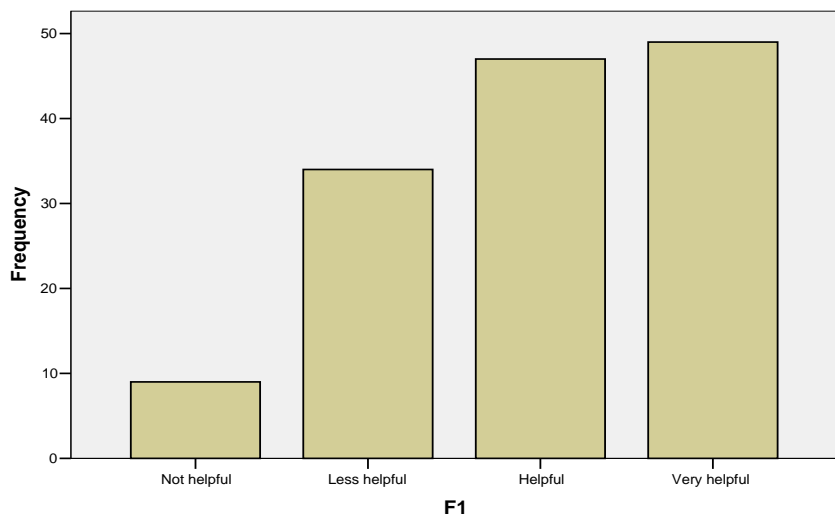

Mean $=2.98$

$\mathrm{N}=139$

With a mean score of 2.98 for this activity, respondents of this survey found that the reading at home activity was not clearly helpful although 35.3 percent of respondents chose the activity as very helpful.

Table 8. Watching TV in English

\begin{tabular}{|c|c|c|c|c|c|}
\hline \multicolumn{2}{|c|}{} & Frequency & Percent & $\begin{array}{c}\text { Valid } \\
\text { Percent }\end{array}$ & $\begin{array}{c}\text { Cumulative } \\
\text { Percent }\end{array}$ \\
\hline \multirow{3}{*}{ Valid } & Not helpful & 2 & 1.4 & 1.4 & 1.4 \\
\cline { 2 - 6 } & Less helpful & 11 & 7.9 & 7.9 & 9.4 \\
\cline { 2 - 6 } & Helpful & 66 & 47.5 & 47.5 & 56.8 \\
\cline { 2 - 6 } & Very helpful & 60 & 43.2 & 43.2 & 100.0 \\
\cline { 2 - 6 } & Total & 139 & 100.0 & 100.0 & \\
\hline
\end{tabular}

Figure 8. Mean, and Histogram for watching TV in English F2

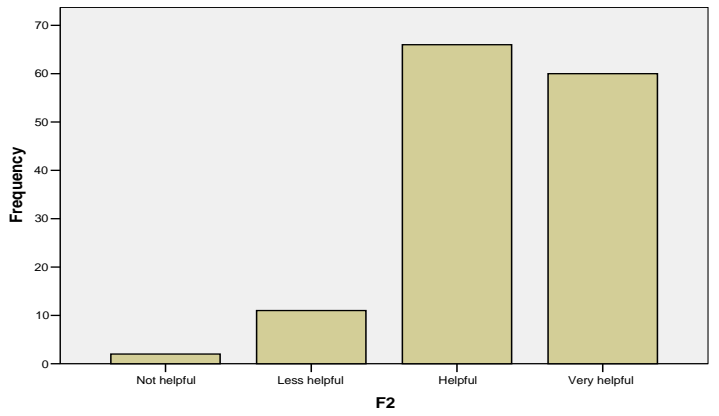

Mean $=3.32$

$\mathrm{N}=139$ 
As indicated in Table.8, 90.7 percent of students chose watching television in English as helpful activity to learn English outside classroom. In particular, 47.5 percent of students found that the activity is helpful and 43.2 percent of them found it very helpful.

\section{Table 9. Listening to CDs and Cassettes}

\begin{tabular}{|c|c|c|c|c|c|}
\hline \multicolumn{2}{|c|}{} & Frequency & Percent & $\begin{array}{c}\text { Valid } \\
\text { Percent }\end{array}$ & $\begin{array}{c}\text { Cumulative } \\
\text { Percent }\end{array}$ \\
\hline Valid & Not helpful & 1 & .7 & .7 & .7 \\
\cline { 2 - 6 } & Less helpful & 11 & 7.9 & 7.9 & 8.6 \\
\cline { 2 - 6 } & Helpful & 67 & 48.2 & 48.2 & 56.8 \\
\cline { 2 - 6 } & $\begin{array}{c}\text { Very } \\
\text { helpful }\end{array}$ & 60 & 43.2 & 43.2 & 100.0 \\
\cline { 2 - 6 } & Total & 139 & 100.0 & 100.0 & \\
\hline
\end{tabular}

\section{Figure 9. Mean, and Histogram for listening to CDs and}

\section{Cassettes}

F3

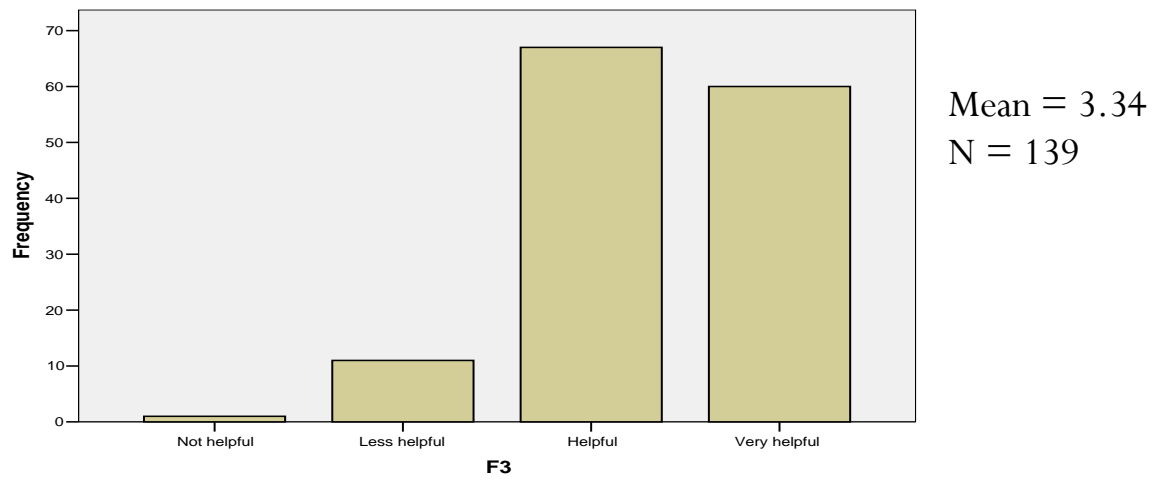

According to the mean of 3.34 for listening to $\mathrm{Cds}$ and cassettes, most students felt that the activity was helpful. 48.2 percent of students found the activity helpful and 43.2 percent of students found it very helpful compared with only 8.6 percent of students chose the activity as either less helpful or not helpful. 
Table 10. Studying English text books

\begin{tabular}{|c|c|c|c|c|c|}
\hline \multicolumn{2}{|c|}{} & Frequency & Percent & $\begin{array}{c}\text { Valid } \\
\text { Percent }\end{array}$ & $\begin{array}{c}\text { Cumulative } \\
\text { Percent }\end{array}$ \\
\hline \multirow{3}{*}{ Valid } & Not helpful & 4 & 2.9 & 2.9 & 2.9 \\
\cline { 2 - 6 } & Less helpful & 25 & 18.0 & 18.0 & 20.9 \\
\cline { 2 - 6 } & Helpful & 66 & 47.5 & 47.5 & 68.3 \\
\cline { 2 - 6 } & Very helpful & 44 & 31.7 & 31.7 & 100.0 \\
\cline { 2 - 6 } & Total & 139 & 100.0 & 100.0 & \\
\hline
\end{tabular}

Figure 10. Mean, and Histogram for studying English text books

F4

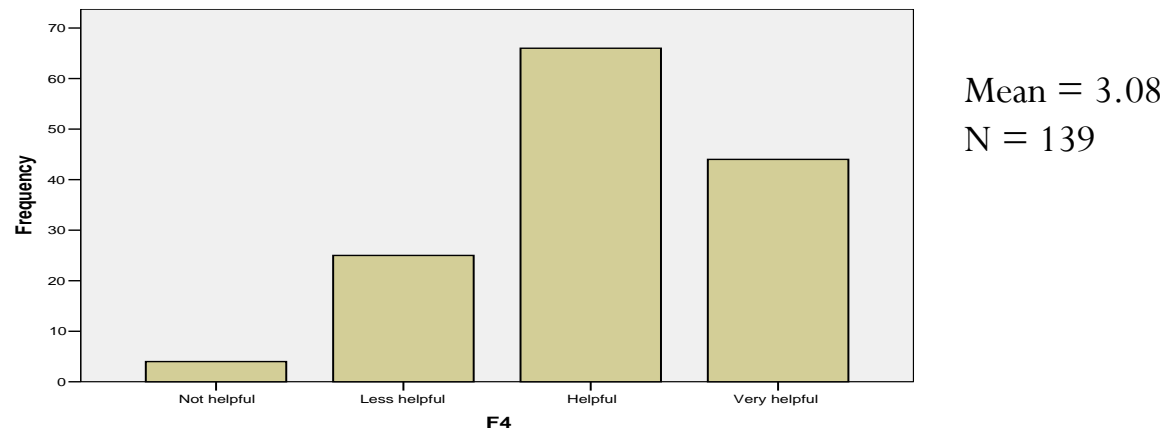

The data in Table and Figure. 10 indicated that respondent found that studying English text books at home helpful (a mean score of 3.08) with 79.2 percent of students found the activity either helpful or very helpful.

Table 11.Talking to friends in English

\begin{tabular}{|c|c|c|c|c|c|}
\hline \multicolumn{2}{|c|}{} & Frequency & Percent & $\begin{array}{c}\text { Valid } \\
\text { Percent }\end{array}$ & $\begin{array}{c}\text { Cumulative } \\
\text { Percent }\end{array}$ \\
\hline \multirow{7}{*}{ Valid } & Not helpful & 1 & .7 & .7 & .7 \\
\cline { 2 - 6 } & Less helpful & 10 & 7.2 & 7.2 & 7.9 \\
\cline { 2 - 6 } & Helpful & 43 & 30.9 & 30.9 & 38.8 \\
\cline { 2 - 6 } & Very helpful & 85 & 61.2 & 61.2 & 100.0 \\
\cline { 2 - 6 } & Total & 139 & 100.0 & 100.0 & \\
\hline
\end{tabular}


Figure 11. Mean, and Histogram for talking to friends in English

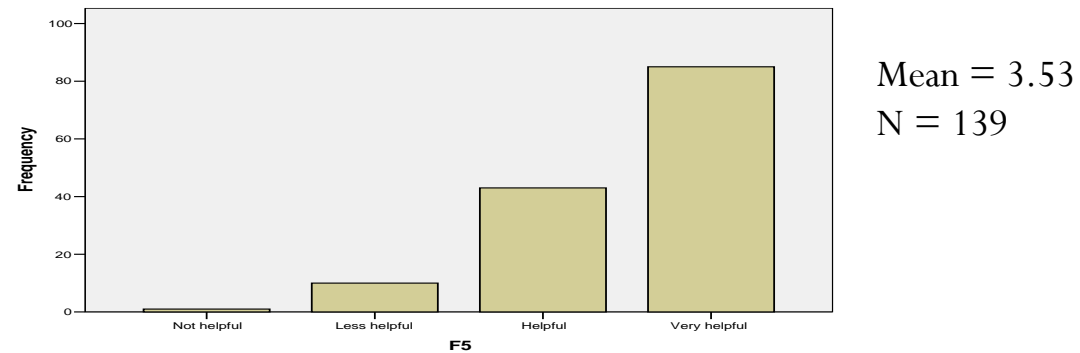

The mean of 3.53 for talking to friends in English as outside classroom activity showed that students found the activity was helpful. In particular, 30.9 percent of students chose the activity as helpful and 61.2 percent of students chose it as very helpful as opposed to only 7.2 percent less helpful with 0.7 percent not helpful.

Table 12. Listening to English program

\begin{tabular}{|c|c|c|c|c|c|}
\hline \multicolumn{2}{|l|}{} & Frequency & Percent & $\begin{array}{c}\text { Valid } \\
\text { Percent }\end{array}$ & $\begin{array}{c}\text { Cumulative } \\
\text { Percent }\end{array}$ \\
\hline Valid & Not helpful & 1 & .7 & .7 & .7 \\
\hline & Less helpful & 14 & 10.1 & 10.1 & 10.8 \\
\hline & Helpful & 58 & 41.7 & 41.7 & 52.5 \\
\hline & Very helpful & 66 & 47.5 & 47.5 & 100.0 \\
\hline \multicolumn{2}{|c|}{ Total } & 139 & 100.0 & 100.0 & \\
\hline \multicolumn{2}{|r|}{}
\end{tabular}

Figure 12. Mean, and Histogram for listening to English program

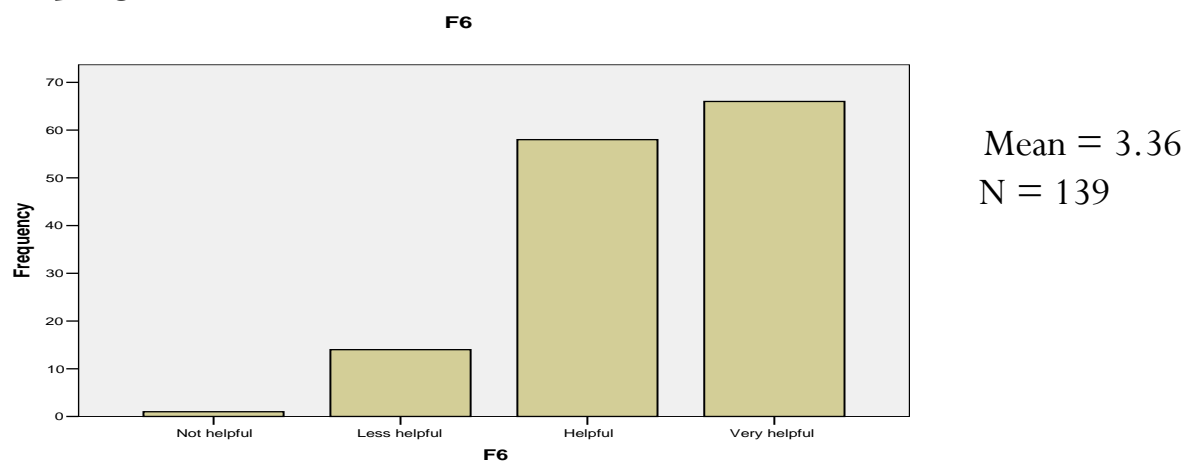


The overall mean of 3.36 (Figure. 12) for listening to English program showed that respondents found the activity helpful. 41.7 percent of respondents chose the activity as helpful and 47.5 percent of students found the activity very helpful compared with only 10.8 percent found it less helpful and not helpful.

Table 13. Frequencies and Percentages for using English to foreigner

\begin{tabular}{|c|c|c|c|c|c|}
\hline \multicolumn{2}{|c|}{} & Frequency & Percent & $\begin{array}{c}\text { Valid } \\
\text { Percent }\end{array}$ & $\begin{array}{c}\text { Cumulative } \\
\text { Percent }\end{array}$ \\
\hline Valid & Not helpful & 5 & 3.6 & 3.6 & 3.6 \\
\cline { 2 - 6 } & Less helpful & 10 & 7.2 & 7.2 & 10.8 \\
\cline { 2 - 6 } & Helpful & 42 & 30.2 & 30.2 & 41.0 \\
\cline { 2 - 6 } & Very helpful & 82 & 59.0 & 59.0 & 100.0 \\
\cline { 2 - 6 } & Total & 139 & 100.0 & 100.0 & \\
\hline
\end{tabular}

Figure 13. Mean, and Histogram for using English to foreigner

F7

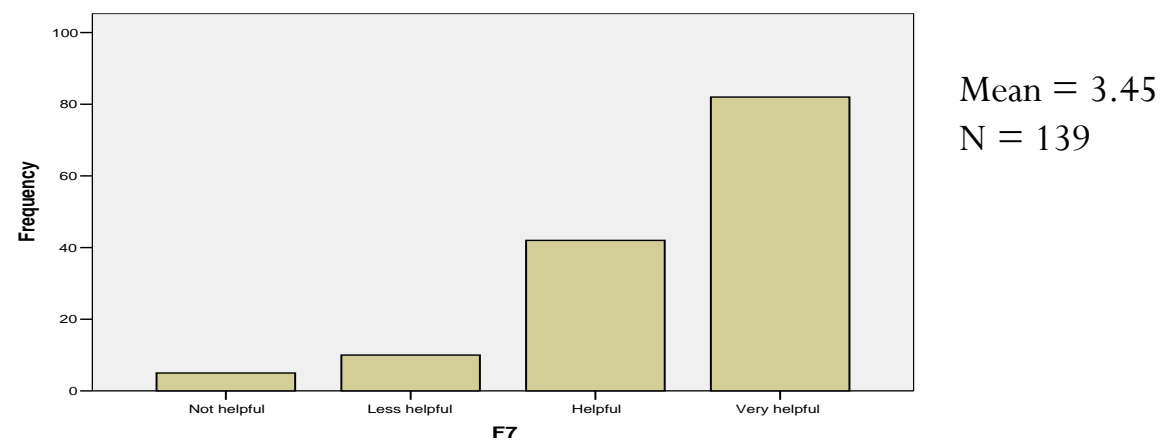

According to the results shown in Table and Figure.7, most students found using English to foreigner either helpful or very helpful $(89.2 \%)$.

\section{Comparison across Activities}

Based on the means and percentage below showed the preferred activities chosen by all students from non-English Department which are ranked based on the highest to the lowest 
percentage. The highest percentage indicated that the students nominated the activity as the most preferred activity, and so forth. The table showed that having conversation is the most preferred activity in classroom in which $92.8 \%$ of students chose the activity with a mean score of 3.60. Playing games is the least preferred activity students found with only $59 \%$ of respondents chose it.

Means and Percentage for Students' Preferred Activities in Classroom (Ranked from the highest to the lowest percentage)

\begin{tabular}{|c|l|c|c|}
\hline No & \multicolumn{1}{|c|}{ Survey Item } & Means & $\mathbf{\%}$ \\
\hline 4 & Having conversations & 3.60 & 92.8 \\
\hline 2 & Listening to Cds and Cassettes & 3.27 & 84.2 \\
\hline 5 & Watching Film or Video & 3.14 & 81.3 \\
\hline 1 & Reading & 3.21 & 79.8 \\
\hline 6 & Writing in notebook & 3.07 & 77 \\
\hline 3 & Playing games & 2.73 & 59 \\
\hline
\end{tabular}

It can be seen from the means and the percentage below that the three most preferred activities that students chose were talking to friends in English (mean score $=3.53$ and percentage $=92.1 \%$ ), Listening to Cds and Cassettes (3.34 of mean score and percentage of 91.4\%), and watching $\mathrm{Tv}$ in English (mean score=3.32 and percentage $=90.7 \%$ ) respectively. Whereas, studying English text books with a mean score of 3.08 and reading at home with a mean score 2.98 were the second least preferred activities respectively.

\section{Means and Percentage for Outside Class Activities (Ranked from the highest to the lowest Percentage)}

\begin{tabular}{|c|l|c|c|}
\hline No & \multicolumn{1}{|c|}{ Survey Item } & Means & \% \\
\hline 5 & Talking to friends in English & 3.53 & 92.1 \\
\hline 3 & Listening to Cds and Cassettes & 3.34 & 91.4 \\
\hline 2 & Watching TV in English & 3.32 & 90.7 \\
\hline 7 & Using English to foreigners & 3.45 & 89.2 \\
\hline
\end{tabular}




\begin{tabular}{|c|l|c|c|}
\hline 6 & Listening to English program & 3.36 & 89.2 \\
\hline 4 & Studying English text books & 3.08 & 79.2 \\
\hline 1 & Reading at home & 2.98 & 69.1 \\
\hline
\end{tabular}

According to percentage and overall means shown in Table 14, Indonesian students in this study, as a whole, have expressed that their least preferred activities for in learning English in the classroom are reading activity, writing in notebooks, and playing games. Seemingly, the students' preferences are not in accordance with the focus of teaching English in university level in Indonesia. As explained in review of the literature in previous chapter, the focus of learning English is reading as many reference books are written in English (Nababan, 1991).

Overall, students found conversation activities were very helpful (92.8\%). 69\% of students found it very helpful and $23.7 \%$ found it helpful. This result is a challenge for teachers to have these activities in classroom as Krashen (1982) states that real life conversation can be the best medium to provide comprehensible input, which students can not find outside the classroom.

Meanwhile, regarding activities outside classroom (Table 15), students found talking to friends in English was helpful activity with 92.1 percent of students chose this activity as preferred activity. They found reading at home was the least preferred activity to learn English outside classroom. According to Ellis (1992) there two ways learners can do to obtain comprehensible input. Firstly, learners should interact with native speakers in which the interactions will occur. Another way is through learners' communication strategies which will help them to cope with communicating problems in limited target language resources. Talking to friends in English is one of ways for learners to use their communication strategies in English as a foreign language learning context where native speakers are hard to find.

\section{DISCUSSION}

The information generated from the results of this study will be useful for improving teaching and learning practice in my university. The students' preferred activities in learning English will be helpful for 
teachers when design learning activities that suit students in terms of their interest. This study has shown that students prefer conversation activities in class. According to this preference, teachers should take conversation activities into account when constructing instructional design. As I explained in literature review, conversation can be best medium for students to get comprehensible input, which is a main element in language acquisition.

In addition, Ellis (1992) states that comprehensible input is negotiation matters which mean that teachers are advised to create activities in which interactions will occur to generate productive utterances by learners in the conversation. Ellis further explains that in order to make language classroom more successful, the teachers should stop interfering in the learning process and give opportunities for learners to engage in interaction that allows the learners to develop naturally in communicative activities.

Thus, teachers can use conversation activities to provide comprehensible input for the students. One point to bear in mind that the topic of conversation built in classroom should reflect students' interest and come from their life. In this study, students prefer their teachers to help them to talk about their interest. This preference will be rich resource for teachers to develop the topic of the conversations that can be very much helpful and meaningful than topic which does not originally derive from students' real life.

The results of this study have also shown that students found reading activity both in classroom and outside classroom not helpful or preferable. The researcher assumed that students prefer not to choose reading as helpful activity as a result of monotonous reading lesson presented to students by the teachers. In conventional reading lesson, students are required to read the text chosen by teachers. Then, teachers explain some words which students are not familiar with. Next, teachers and students translate the reading text into their first language. Finally, students are asked to answer the questions following the text. If there is limited time to complete the task in classroom, the teachers usually assign the task as homework for students to complete at home. 
There are some ways that teachers can do to avoid students feeling bored with a reading lesson. One way is by choosing familiar topic to the students. In doing so, the teachers can negotiate the topic with students. The relevance of the topic for students is something to consider. Krashen (1989) states that self-selected reading can encourage students to be enthusiastic about the reading. Once students get interested in reading, they will comprehend the text better. Another way is by allowing students to have reading for pleasure. The teachers can initiate this activity by asking students about their reading habits outside of school. Then, the teachers can assign the students to make report about their reading in written form so that teachers can involve by giving comments in the effort to support the students reading habits. The next step, teachers can ask students to find the reading topic that is relevant to their major field of study and again ask them to make report to assess the students' comprehension of the topic chosen by students. Krashen (1989) points out that there are relationship between reading for pleasure and reading comprehension, grammatical development, and writing style.

This study has provided some information regarding students preferred activities in learning English in a foreign language context. Some evidence of this study suggest that Indonesian non-English department students prefer having conversation activities in classroom, they like their teachers helping them to talk about their interest instead of allowing them to find their own mistakes. The students prefer having English activities in small groups and practicing English to studying English alone. For outside classroom activities, the students prefer talking to friends in English to reading at home.

One important point that should be stressed is that the findings of this study can only provide information to understand the learning preferences of Indonesian non-English department students in learning English. The findings cannot be used to generalize all Indonesian students. The students whose major field is English, for example, may have different preferred activities in learning English. 


\section{CONCLUSION}

A final conclusion I draw from the findings is that as an English teacher, I am going to use students' preferred activities to improve my teaching practice in classroom and to encourage my students from non-English department students to learn English outside classroom. English activities undertaken both inside and outside classroom should take comprehensible inputs into account. Students' communication activities should be in the form of group works and pair works. In my effort to encourage students to talk in English, their interest is a good topic to discuss in order to get the students actively involved in the activities I designed.

In addition, in order to accommodate students' preferred activities in learning English, I am going to implement some techniques derived from the findings of this study. Firstly, I will encourage my students to watch English programs on TV. By watching the programs, they will learn how English speaker pronounce the words. Intonation, listening skill, and English expression can also be learnt. For those who like writing, I will assign them to write English poems, short story, and simple journal that expose their interest and real life.

In terms of learning vocabulary, I will encourage my students to have reading for pleasure. This activity can help students learn new words as well as learn to comprehend an English text. Magazine, short story, newspaper, and novel are authentic sources of reading for pleasure. For those who prefer listening to $\mathrm{Cds}$ and Cassettes, presenting English song in classroom is a helpful mean to learn English. Vocabulary, pronunciation as well as grammar can be learnt from this activity. For those who like having conversation with friends, English drama performance can be an effective way to practice their speaking skill through roles that they act.

At last, I recommend that students' preferred activities in learning English are very helpful information that English teachers should consider in their efforts to improve their ways of teaching English. There are various activities that English teachers can try to implement inside and outside classroom to meet students' interest in order to improve the quality of teaching and learning English, in particular for non-English department students. 
In addition, as there is increasing interest in the ways in which non-English Department students can be supported in their learning of English not only in Indonesia but also in other ASEAN countries, the findings of this study will be also useful knowledge for education system policy makers, curriculum designers, and teachers working in the area of English language teaching in South East asia.

\section{REFERENCES}

Berns, M (1990). 'Second' and 'Foreign' in Second Language Acquisition/Foreign Language Learning: A Sociolinguistic Perspective. In B. Van Patten and J.F Lee (Eds.), Second Language Acquisition-Foreign Language Learning. Multilingual Matters LTD, Philadelphia.

Bradford, A. (2007). Motivational orientations in under-researched FLL contexts: Finding from Indonesia. RELC Journal, 38(3), 302-323.

Cohen, L. M \&Morrison, K. (2000). Research Methods in Education. Fifth Edition. London Publisher Routledge Falmer. London

Crowl, T. K. (1983). Fundamentals of Educational Research. Brown and Benchmark Publisher, Dubuque. USA

Ellis, R. (1992). Second Language Acquisition and Language Pedagogy. Multilingual Matters LTD. UK

Exley, B. E. (2005). Teachers' professional knowledge bases for offshore education: Two case studies of western teachers working in Indonesia.(PhD thesis). Brisbane: Queensland University of Technology.

Kirkpatrick, A. (2007). World Englishes: Implications for international communication and English language teaching. Cambridge, England: Cambridge University Press.

Krashen, S. D. (1982). Principles and Practices in Second Language Acquisition. Pergamon Press. Oxford.

Lie, A. (2007). Education policy and EFL curriculum in Indonesia: Between the commitment to competence and the quest for higher scores. TEFLIN Journal, 18(1), 1-14. 
Mbato, C. L. (2013). Facilitating EFL learners' self regulation in reading: Implementing a metacognitive approach in an Indonesian higher education context. Lismore, NSW: Southern Cross University.

Nababan, P. W. J. (1991). Language in Education: The Case of Indonesia. International Review of Education, Springer Netherland. Vol.37. No.1

Nunan, D. (1991). Language Teaching Methodology. Prentice Hall International (UK) LTD. London

Oxford, R. L. (1990). Language learning strategies: What every teacher should know. Boston: Heinle \& Heinle Publisher.

Phan, S. (2002). A Cambodian Institute of Foreign Language Student Survey. (Master Thesis). La Trobe University. Australia

Sawir, E. (2005). Language difficulties of international students in Australia: The effects of prior learning experience. International Education Journal, 6(5), 567-580.

Setiyadi, B. (2001). Language learning strategies: Classification \& pedagogical implication. TEFLIN, 12(1).

Sugirin (1999). Studying the academic reading comprehension process:

Responding to methodological concerns. Paper presented to HERDSA Annual International Conference. Melbourne, 12-15 July.

Sulistiyo, U. (2009). Learning English in an Indonesian university: A study of learners' preferred activities. La Trobe University.

Suryati, N. (2013). Developing an effective classroom interaction framework to promote lower secondary school students' English communicative competence in Malang, East Java, Indonesia (Unpublished dissertation). The University of Newcastle, NSW.

Wiersma, W. and Jurs, S. G.(2005). Research Methods in Education. Pearson Education Inc. Boston

Willing, K. (1988). Learning Strategies as Information Management: Some Definitions for a Theory of Learning Strategies. Prospect,3.pp.139155

Wright, T.(2005). Classroom Management in Language Education. Palgrave Macmillan. New York. 
Yulia, Y. (2013). Teaching challenges in Indonesia: Motivating students and teachers' classroom language. Indonesia Journal of Applied Linguistics, 3(1), 1-16.

Yuwono, G. (2005). English language teaching in decentralised Indonesia: Voices from the less privileged schools. Paper presented at the AARE 2005 International Education Research Conference, The University of Sydney, Sydney, NSW. 